\title{
Promising results from cyclophosphamide based immunosuppression therapy of thrombotic thrombocytopenic purpura
}

\author{
Obiecujące rezultaty użycia immunosupresji opartej na cyklofosfamidzie w leczeniu plamicy \\ małopłytkowej zakrzepowej
}

\author{
Renata Guzicka-Kazimierczak¹, Arkadiusz Kazimierczak², Jeremy Clark³ \\ ${ }^{1}$ Klinika Hematologii Pomorskiego Uniwersytetu Medycznego w Szczecinie \\ ul. Unii Lubelskiej 1, 70-252 Szczecin \\ Kierownik: prof. dr hab. n. med. Barbara Zdziarska \\ ${ }^{2}$ Klinika Chirurgii Naczyniowej, Ogólnej i Angiologii Pomorskiego Uniwersytetu Medycznego w Szczecinie \\ al. Powstańców Wlkp. 72, 70-111 Szczecin \\ Kierownik: prof. dr hab. n. med. Piotr Gutowski
}

${ }^{3}$ Zakład Biochemii Klinicznej i Molekularnej Pomorskiego Uniwersytetu Medycznego w Szczecinie

al. Powstańców Wlkp. 72, 70-111 Szczecin

Kierownik: prof. dr hab. n. med. Andrzej Ciechanowicz

\section{SUMMARY}

Purpose: Thrombotic thrombocytopenic purpura is a rare disease. Therefore, the small numbers of patients in trials results in statistically weak evidence supporting treatment guidelines. The aetiology of this disease is based on a deficiency of metalloproteinase 13 (ADAMTS-13), which leads to the creation of von Willebrand factor polymers and platelet microthrombosis in small vessels. Treatment relies on plasma exchange. Immunosuppression based on cyclophosphamide is not recommended in current guidelines. The aim of this study was to assess the early and long-term effects of treatment, and to evaluate therapy prognostic factors.

Material and methods: This was a retrospective study of 10 patients hospitalized 14 times due to new or recurrent onset of TTP. Currently recommended treatment was used in all cases, including total plasma exchange (range $0.5-2$ plasma volume). The volume of exchange plasma was $24.6 \mathrm{~L}$ (mean) over 20 days (median). All patients received glucocorticosteroids. Immunosuppression (based on cyclophosphamide in 7 cases) was utilized in $70 \%$ of patients ( 9 patients).

Results: Of all 11 patients 9 (70\%) survived and achieved remission. Fifty percent of patients stayed in long-lasting remission. Average follow-up time was 36 months (median 14.5 months, range 10 days to 108 months). Factors improving the chance of remission were: age below 55 years $(p<0.05)$, no tachycardia on admission to hospital ( $\mathrm{p}<0.001)$, and immunosuppression based on cyclophosphamide ( $\mathrm{p}=0.032)$.

Conclusions: Presence of tachycardia on TTP onset and age above 55 years reduce the survival and remission rate. Remission from TTP is suggested to be caused by immunosuppression based on cyclophosphamide.

Key words: thrombotic thrombocytopenic purpura, cyclophosphamide, total plasma exchange, plasmapheresis, immunosuppression.

\section{STRESZCZENIE}

Wstęp: Plamica małopłytkowa zakrzepowa (thrombotic thrombocytopenic purpura - TTP) jest chorobą występującą rzadko. $\mathrm{Z}$ tego powodu mała liczba pacjentów w badaniach jej poświęconych skutkuje słabymi statystycznie dowodami wspierającymi zalecenia terapeutyczne. Przyczyną choroby jest niedobór metaloproteinazy 13 (ADAMTS-13), który prowadzi do powstawania polimerów czynnika von Willebranda i zatorów płytkowych w małych naczyniach. Leczenie polega na wymianie osocza. Immunosupresja opierająca się na cyklofosfamidzie nie jest rekomendowana w aktualnych zaleceniach.

Celem pracy była ocena wczesnych i odległych wyników leczenia oraz określenie czynników prognostycznych.

Materiał i metody: Badanie obejmowało retrospektywną ocenę 10 chorych, hospitalizowanych 14 razy z powodu pierwotnego lub nawrotowego wystąpienia TTP. Zalecane leczenie zastosowano we wszystkich przypadkach, włączając całkowitą wymianę osocza (0,5-2 objętości osocza), którego objętość wyniosła średnio

24,6 L w czasie 20 dni (mediana). Wszyscy chorzy otrzymali glukokortykosteroidy. Immunosupresja (oparta na cyklofosfamidzie w 7 przypadkach) była dodatkowo użyta w 70\% (9 pacjentów).

Wyniki: Spośród 11 chorych 9 (70\%) przeżyło i uzyskało remisję. Połowa utrzymała długoterminową remisję. Średni czas obserwacji wyniósł 36 miesięcy (mediana 14,5 miesięcy, od 10 dni do 108 miesięcy). Czynniki poprawiające szansę uzyskania remisji to: wiek do 55 lat $(\mathrm{p}<0,05)$, niestwierdzenie tachykardii przy przyjęciu $(p<0,001)$ i immunosupresja oparta na cyklofosfamidzie $(p=0,032)$.

Wnioski: Tachykardia oraz wiek powyżej 55 lat stwierdzone przy rozpoznaniu TTP zmniejszają szanse przeżycia i remisji. Immunosupresja oparta na cyklofosfamidzie prawdopodobnie zwiększa szansę uzyskania remisji w TTP.

Słowa kluczowe: plamica małopłytkowa zakrzepowa, cyklofosfamid, całkowita wymiana osocza, plazmafereza, immunosupresja. 


\section{INTRODUCTION}

Moschowitz syndrome, otherwise known as thrombotic thrombocytopenic purpura (TTP), is one of a many possible causes leading to thrombotic microangiopathy $[1,2,3]$. The frequency in the world's population is 37 per 100000 people. The disease is slightly more often found in females than in males (1.5:1), and usually between the ages of 30 and 40 years $(y)[1,2,4]$. Because it is a very rare condition, only a limited number of reports exist in the literature. Moreover, the number of reported cases is very small in all studies (usually less then 30 cases, and the maximum number is less than 100) $[4,5,6]$. Consequently, this has led to a lack of appropriate scientifically-supported treatment guidelines (and a lack of randomized trials as well) [3]. Most reports are retrospective studies based on an author's experience and, therefore, every new group of patients reported in the literature is of value because this improves the chances of more accurate collective scientific research.

The aetiology of TTP is an autoimmune response based on the creation of immunoglobulins against metalloproteinase 13 , which consists of "A Disintegrin and Metalloproteinase with a ThromboSpondin type 1 motif, member 13"; ADAMTS-13 [2, 7]. Physiologically metalloproteinase 13 is responsible for cleaving large vWF multimers, and a deficiency of ADAMTS-13 leads to an increase in vWF multimers and triggers the symptoms of TTP. These multimers bind platelet glycoproteins Ib/IX, V and IIb/IIIa, which leads to the thrombosis of small vessels $[1,2,8]$. In the case of congenital TTP (Upshaw Schuman syndrome) there is an inherited lack of ADAMTS-13 because of a mutation in the metalloproteinase coding gene $9934[2,5]$. Other causes of TTP include idiopathic TTP or TTP related to rheumatoid diseases (systemic lupus erythematosus - SLE), cancer or drug related causes (e.g. ticlopidine, quinidine or some cytostatins). Bacterial infections, HIV and pregnancy can also cause TTP [9].

Moschowitz syndrome can also be triggered by transplantation. But in this case, and contrary to classic TTP, the onset is usually asymptomatic with normal metalloproteinase concentration, and the diagnosis is confirmed by kidney biopsy [9].

Thrombotic thrombocytopenic purpura typically has a triplet of symptoms: haemolytic anaemia, thrombocytopenia and some neurological disorders [10], as micro-embolism usually affects the brain. The variety of further symptoms typically makes recognition of TTP difficult, and patients are subsequently often treated by different specialists before correct diagnosis [10]. Neurological symptoms are such that patients might suffer headache, paresis, paralysis or consciousness disturbances or seizures. The most common cardiological symptoms are acute coronary syndromes and resistant hypertension. In cases where visceral arteries are affected patients might present with a picture similar to acute pancreatitis. A temperature rise is also possible $[1,2]$.

Diagnosis of TTP is based on the confirmation of the presence of inhibition and a decreased concentration in ADAMTS-13 [1, 2, 3 , 7]. Treatment of TTP can be difficult and complicated. The first line treatment base is plasma transfusion with fresh frozen plasma (FFP; 40-60 mL/kg body mass) and plasmapheresis. Treatment with FFP and plasmapheresis together is termed therapeutic plasma exchange (TPE) $[1,2,3,4]$. Transfusion with FFP supplies the missing ADAMTS-13. The initial volume of FFP (before plasmapheresis begins) is up to a maximum of $30 \mathrm{~mL} / \mathrm{kg}$ body mass, to reduce the risk of transfusion-associated dyspnoea (TAD). After this, the plasmapheresis removes auto-antibodies and cytokines, which tend to damage the endothelium. Treatment should raise the platelet (PLT) count and reduce lactate dehydrogenase (LDH) concentration, as well as remove the clinical symptoms. If the initial treatment is not effective during the first 3 days, glucocorticoids are then introduced. However, in the case of further deterioration immunosuppression is also started e.g. with cyclophosphamide (Endoxan, Baxter Oncology GmbH, Frankfurt, Germany) or vincristine (Oncovin, Cellpham GmbH, Hannover, Germany) or alternative antibodies are used: anti-CD20 (Rituximab, Mabthera, Roche, Mannheim, Germany) [1, 2, 3, $11,12]$. If TTP is left untreated, the death rate can reach $90 \%$. Proper treatment reduces the death rate to $20-25 \%[3,13,14]$, but in any case the risk of death remains high. Moreover, scientifically confirmed evidence for the appropriate treatment of TTP does not exist, and therefore we compare our results with data from other centres, especially in regard to the treatment of resistant cases.

An attempt at the recognition of prognostic factors in the treatment of TTP, and the assessment of early and long-term effects of treatment.

\section{MATERIAL AND METHODS}

\section{Source}

A retrospective study based on patient registry files from University Hospital no. 1 (SPSK no. 1) of the Pomeranian Medical University in Szczecin (PMU).

\section{Material}

A group of 10 patients with TTP ( 5 females and 5 males) treated at the Haematology Department at PMU (SPSK no. 1) during the last 10 years. This involved 14 hospitalization periods because of TTP recurrence in 2 patients (once with 1 male patient and 3 times with 1 female patient). (This does not give a significant difference in recurrence rate depending on gender). The mean age in the group was $41 \mathrm{y}$ (median $36 \mathrm{y}$, range 24 to $66 \mathrm{y}$ ), body mass $84 \mathrm{~kg}$ (median $88 \mathrm{~kg}$, range 60 to $101 \mathrm{~kg}$ ) and height 170 $\mathrm{cm}$ (median $163 \mathrm{~cm}$, range 158 to $194 \mathrm{~cm}$ ).

\section{Symptoms on admission}

Three patients were completely healthy before the onset of TTP. Seven patients had concomitant diseases: primary hypertension in 3 patients, diabetes in two patients, and chronic kidney disease in 1 patient. Three patients had chronic limb ischemia (arteriosclerosis, after limb peripheral by-pass), 1 patient had schizophrenia, and 1 heroin abuse in their medical history. The most common symptoms directing the patient to hospital 
were neurological disorders $(n=10)$, fever $(n=3)$, abdominal pain $(n=2)$ and purpura $(n=3)$. Two cases were reported due to a bleeding complication after vascular surgery. General weakness and acute pancreatitis were listed for 2 patients. Paresis was the most common neurological symptom $(n=3)$, then paresthesis $(n=2)$, and in single cases: seizure, aphasia, amaurosis, dizziness and a consciousness disorder.

\section{Aetiology}

Drug related aetiology was suspected in 4 cases: heroin abuse $(\mathrm{n}=1)$, NSAIDs ( $\mathrm{n}=2)$ and Fluanox Depot (Lundbeck, Canada) $(n=1)$. Systemic lupus erythematosus was eventually diagnosed in 1 patient with recurrent TTP (with recurrence 3 times). Checks for ADAMTS-13 inhibition and ADAMTS-13 activity were performed during 10 hospitalizations. In all cases inhibition was present, together with a low concentration of ADAMTS-13 13. In the cases of recurrent TTP these tests were not repeated, and diagnosis was based only on the clinical picture.

TABLE 1. Initial morphological and biochemical results

\begin{tabular}{lccc}
\multicolumn{1}{c}{$\begin{array}{c}\text { Morphological and } \\
\text { biochemical results }\end{array}$} & Median & Minimum & Maximum \\
\hline Leukocytes (G/L) & 10 & 5.2 & 22 \\
\hline Erythrocytes (T/L) & 2.9 & 1.8 & 4.8 \\
\hline Platelets (G/L) & 13 & 6.0 & 79 \\
\hline Haemoglobin (mmol/L) & 8.8 & 6.1 & 13 \\
\hline Haematocrit (\%) & 26 & 17 & 37 \\
\hline Reticulocytes (G/L) & 77 & 10 & 190 \\
\hline $\begin{array}{l}\text { Lactate dehydrogenase } \\
\text { (mmol/L) }\end{array}$ & 1800 & 600 & 5900 \\
\hline $\begin{array}{l}\text { Aspartate aminotransferase } \\
\text { (mmol/L) }\end{array}$ & 97 & 44 & 4100 \\
\hline $\begin{array}{l}\text { Alanine aminotransferase } \\
\text { (mmol/L) }\end{array}$ & 79 & 16 & 1600 \\
\hline $\begin{array}{l}\text { Bilirubin (mmol/L) } \\
\text { Gamma glutamyl transpeptidase } \\
\text { (mmol/L) }\end{array}$ & 82 & 19 & 120 \\
\hline $\begin{array}{l}\text { D-dimer (ng/L) } \\
\text { rate (mL/min/1.73 msq) }\end{array}$ & 5.7 & 1.1 & 73 \\
\hline $\begin{array}{l}\text { Creatinine (mmol/L) } \\
\text { Uric acid (mmol/L) }\end{array}$ & 7.9 & 3.9 & 17 \\
\hline
\end{tabular}

Among biochemical parameters LDH (lactate dehydrogenase) was elevated in all cases, as well as the presence of elevated reticulocyte count and D-dimers, anaemia and thrombocytopenia.

\section{Treatment}

All patients received the currently recommended therapy $[1,2$, $3,4]$, and plasmapheresis was used in all cases, as well as plasma transfusion with FFP. In 11 hospitalizations the FFP was transfused without human antihaemophilic globulin (Regionalne Centrum Krwiodawstwa i Krwiolecznictwa, Szczecin, Poland), but in 3 hospitalizations transfusion of FFP was used both with, and without, human antihaemophilic globulin in the same patient (at different treatment periods following onset or recurrence of TTP). The mean number of FFP transfusion days (d) was $25 \mathrm{~d}$ (median $21 \mathrm{~d}$, range 5 to $60 \mathrm{~d}$ ). The mean number of plasma units given was $240 \mathrm{U}$ (median $200 \mathrm{U}$, range 47 to $700 \mathrm{U}$ ). The mean plasma volume given was $22 \mathrm{~L}$ (median $25 \mathrm{~L}$, range 13 to $29 \mathrm{~L}$ ). The mean number of days of therapeutic plasma exchange (TPE = plasmapheresis together with FFP transfusion) was $22 \mathrm{~d}$ (median $20 \mathrm{~d}$, range 4 to $58 \mathrm{~d}$ ). The TPE range was between 0.5 and 2 total body volume plasma exchange. All patients received glucocorticosteroids (GKS) over a median of 9 days (range 1 to $76 \mathrm{~d}$ ). The fifth day was the most common day to start steroid treatment (median 5 days, range 1 to $32 \mathrm{~d}$ ). In the group with good early results (in 7 hospitalizations) steroids were usually introduced during the first 4 days of treatment. Immunosuppression, based on cyclophosphamide, was utilized in 9 hospitalizations (7 patients). Five patients did not receive immunosuppressants because they died before the treatment started. Details of immunosuppressant therapy are presented in Figure 1.

\section{Methodology of results assessment}

We based our study on the assessment of treatment effectiveness between hospitalizations, because there were 2 cases treated repeatedly, but always in a different way during every hospital stay (one patient had 2 hospitalizations and the other patient 3 hospitalizations).

We investigated the dynamic changes in patients' laboratory results, clinical assessments and achievement of endpoints (survival or remission). Long-term results assessments were based on survival and the recurrence rate of TTP. To assess remission we took into account parameters such as: initial morphology and biochemistry (LDH, bilirubin, aspartate aminotransferase, alanine aminotransferase, D-dimers, estimated glomerular filtration rate, uric acid), demographic variables (age, gender, concomitant diseases) and clinical symptoms (neurological, cardiological and others), as well as type of treatment and the dynamics of changes in the above-mentioned parameters.

\section{Statistical analysis}

Statistical analysis was performed with the use of Statistica PL 5.0 (StatSoft, Inc. USA). Shapiro-Wilk's test was utilized to check the normal distribution. U Mann-Whitney tests were used to compare 2 groups of quantitative values in cases without normal distributions. Comparisons of qualitative variables were performed with the use of Fisher exact tests. Regression analysis was used for comparison of 2 quantitative variables. To exclude autocorrelation the Lambda Wilk's test was utilized. Survival assessment was performed based on the KaplanMeier method. Moreover, comparison of survival between the 2 groups was performed using 2 tests: the F Cox test and the Log-rank test (to assess the end stage of follow-up). However, the influence of quantitative variables on survival rate was performed based on the Cox proportional hazards model. Statistically significant differences were defined with $\mathrm{p}<0.05$. 


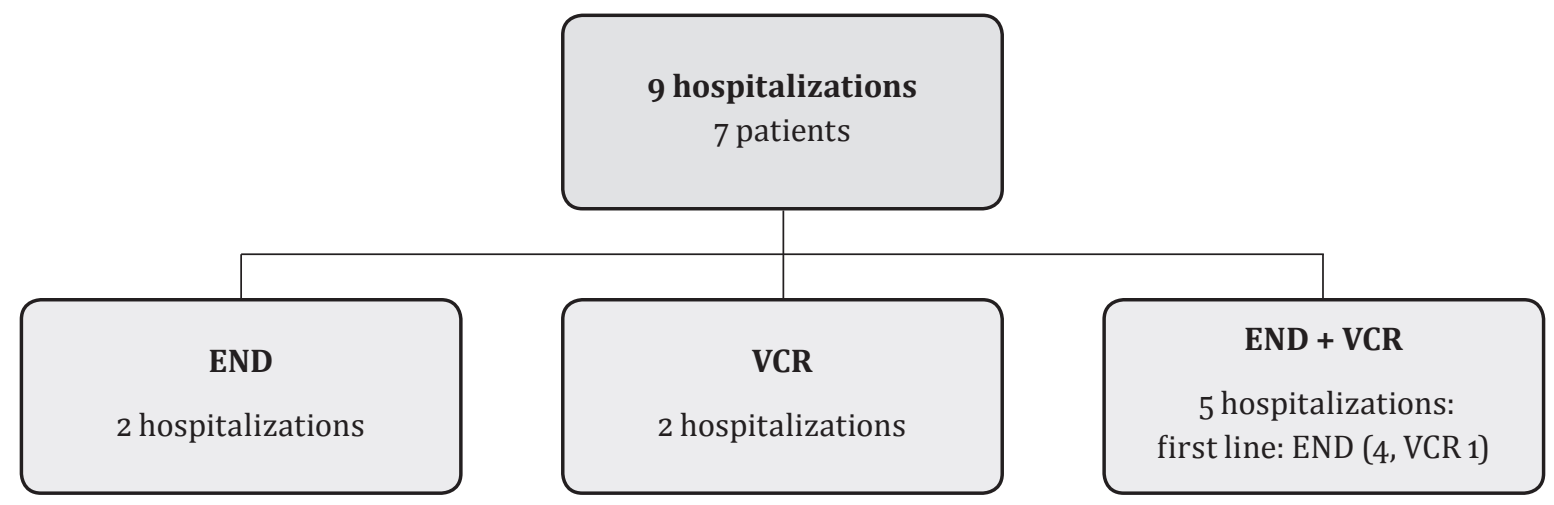

END - Cyclophosphamide (Endoxan, Baxter Oncology GmbH, Frankfurt, Germany); VCR - Vincristine (Oncovin, Cellpham GmbH, Hannover, Germany)

FIGURE 1. Type of immunosuppression

\section{RESULTS}

\section{Treatment course}

The dynamics of changes in morphological and biochemical parameters are presented in Table 2. (Shows when we observed the changes in appropriate factors).

TABLE 2. Dynamics of changes in morphological and biochemical parameters

\begin{tabular}{lccc}
\multirow{2}{*}{ Days to } & \multicolumn{3}{c}{ Number of days } \\
\cline { 2 - 4 } & median & minimum & maximum \\
\hline Increase in PLT count & 4 & 0 & 17 \\
\hline Normalization of PLT count & 6.5 & 0 & 30 \\
\hline Decrease in reticulocyte count & 17.5 & 4 & 30 \\
\hline Reticulocyte normalization & 23 & 18 & 58 \\
\hline Decrease in LDH concentration & 6 & 2 & 40 \\
\hline $\begin{array}{l}\text { Normalization of LDH } \\
\text { concentration }\end{array}$ & 17 & 4 & 43
\end{tabular}

The day on which PLT count normalized correlated with the day on which GKS treatment was started $(p=0.024, r=0.67$, regression equation: Day of PLT normalization $=4.22+0.8 \times$ day of GKS introduction). Intermittent collapse in PLT count was noted in 9 hospitalizations (8 patients). During 7 hospitalizations some neurological complications occurred. There were seizures in 4 hospitalizations, paresis in 2 hospitalizations, and consciousness disturbances in one. Moreover, cardiological complications were noticed during treatment in 5 hospitalizations. Left-sided heart failure occurred in 4 cases, with pulmonary oedema in 2 hospitalizations and resistant hypertension in 2 . In one case hypertension coexisted with severe left-sided heart failure. Additionally, in 2 hospitalizations electrocardiography revealed tachycardia without other cardiological complications. Therefore, these were initially excluded from the severe complications count. Other severe conditions due to respiratory and circulatory failure (TAD) occurred in 6 cases during 6 hospitalizations. In these cases patients were transferred and treated in the Intensive Care Unit (ICU; 5 patients due to circulatory failure and one because of severe disturbance to consciousness). Note that no patient with recurrence of TTP needed an ICU stay. The mean time of ICU stay was $15 \mathrm{~d}$ (median $7 \mathrm{~d}$, range 2 to $58 \mathrm{~d}$ ). During ICU treatment 2 patients developed septic complications (one case with confirmed sepsis). In 3 cases (and 3 hospitalizations) resistant hypertension was noted. Nine patients (during 9 separate hospitalizations) were eventually discharged from the hospital with chronic immunosuppressive therapy, as presented in Table 3.

TABLE 3. Chronic supportive immunosuppression

\begin{tabular}{lc}
\multicolumn{1}{c}{ Type of drug therapy } & Number of hospitalizations \\
\hline Encorton & 1 \\
\hline Metypred & 4 \\
\hline Imuran, Encorton & 1 \\
\hline Endoxan & 1 \\
Dexamethason & 1 \\
\hline Endoxan & 1 \\
\hline Imuran, Metypred & 1 \\
\hline
\end{tabular}

Encorton (Prednisolone, Dagomed Phrama, Pabianice, Poland); Metypred (Methylprednisolone, Orion Pharma, Warsaw, Poland); Endoxan (Cyclophosphamide, Baxter Oncology GmbH, Frankfurt, Germany); Imuran (Asathioprine, GlaxoSmithKline, Ontario, Canada)

Seven out of 10 patients survived following treatment. Three patients died after the first onset of TTP. Relapse in TTP occurred in 2 patients, who at the end of the study remained in remission. One of these had 3 recurrent episodes of TTP; the other patient needed only one further hospitalization. The mean follow-up time was 36 months (median 15 months, range $10 \mathrm{~d}$ to 108 months). The mean time to recurrence was 26 months (median 6.5 months, range 6 to 84 months). Permanent remission after the first TTP episode was achieved in 5 patients.

Factors were compared between patients who died and those who survived (Table 4).

The results shown in Table 4 suggest a lower chance of survival for older and haemodynamically unstable patients (tachycardia), as well as patients treated without immunosuppression. It also seems that patients had a lower chance of survival when they had had a shorter time of the use of plasmapheresis 
TABLE 4. Factors compared between two groups of patients (survivors versus those who died)

\begin{tabular}{|c|c|c|c|}
\hline \multirow{2}{*}{ Factor } & Patients who died & Survivors & \multirow{2}{*}{ p-value } \\
\hline & mean value / number or \% & mean value /number or \% & \\
\hline age (years) & 54.67 & 37.55 & $<0.05$ \\
\hline Initial platelet count (G/L) & 46.00 & 19.18 & ns \\
\hline Initial aspartate aminotransferase (mmol/L) & 554.53 & 85.62 & ns \\
\hline Days to platelet count normalisation (days count) & 0.00 & 12.73 & $<0.05$ \\
\hline Days of plasma transfusion (days count) & 6.67 & 29.82 & $<0.05$ \\
\hline Number of days of plasmapheresis & 5.33 & 26.64 & ns \\
\hline Tachycardia on admission & 3 & 0 & $<0.001$ \\
\hline Neurological complications during treatment & 3 & 4 & $<0.05$ \\
\hline Tachycardia during treatment & 2 & 0 & $<0.01$ \\
\hline Lack of immunosuppression & 3 & 2 & $<0.01$ \\
\hline
\end{tabular}

FFP - fresh frozen plasma

TABLE 5. Cumulative survival rate without recurrence of TTP

\begin{tabular}{lcc}
\multirow{2}{*}{$\begin{array}{c}\text { Time } \\
\text { of follow-up }\end{array}$} & \multicolumn{2}{c}{ Numbers surviving without recurrence of TTP } \\
\cline { 2 - 3 } & immunosuppression & no immunosuppression \\
\hline 12 months & $100 \%$ & $40 \%$ \\
\hline 72 months & $82 \%$ & $20 \%$ \\
\hline 84 months & $49 \%$ & $20 \%$ \\
\hline
\end{tabular}

Differences in cumulative survival rate are significant in the F-Cox test $(p=0.032)$, but not in the Log-rank test $(p>0.05)$

and plasma transfusion. The presence of neurological complications also seemed to decrease the survival rate. Among laboratory results only a lack of platelet count normalization and initially higher ALT concentration seem to correlate with a poor prognosis.

After excluding autocorrelation of factors the final statistical model concerning differences between the 2 groups (survivors versus patients who died) confirmed significant differences between 2 factors: age above 55 years and tachycardia revealed on admission (Wilk's Lambda: 0.08481, F (3.10) = 36.0, $\mathrm{p}<0.00001$ ).

The cumulative survival rate comparison between groups with and without immunosuppression is present in Table 5.

\section{DISCUSSION}

Thrombotic thrombocytopenic purpura is a very rare disease (which is why there are only a small number of cases in our study). Usually, the number of reported cases varies between 5 to 30 , and only a few authors show groups above 50, e.g. in the Oklahoma TTP-HUS Registry [3, 15]. Although there is a risk of misdiagnosis of TTP due to low frequency in the population, in our observation the number of physicians who correctly recognize TTP is rising. The various symptoms of TTP result in patients being spread initially between different departments (e.g. neurology, cardiology, surgery departments) even if initially the patient was diagnosed in an emergency outpatient clinic. Therefore, multidisciplinary arrangements must be made in such studies.

However, neurological symptoms usually seem to dominate the diagnosis, and this is of some importance because the sensitivity of neurological disorders can reach 90\% [1]. In contrast, however, some authors have reported lower (35\%) percentages of neurological symptoms [3].

In our study there seemed to be no relationship between the presence of neurological disorders and death rate, but the appearance of neurological dysfunction during the treatment seemed to be related with worse initial results, the most often occurring dysfunctions being paresis and paresthesis. Temperature rise was a secondary symptom similar to that observed by other authors $[1,2]$. Abdominal pain was the reason for admission in 3 of our cases. Moreover, in 1 case pancreatitis was the initial diagnosis. Similar mistakes in initial diagnosis are typically reported in such cases $[3,10]$. In our study only 1 patient presented with cardiological symptoms, which was the reason for admission. In all hospitalizations we noticed Coombs negative haemolytic anaemia and thrombocytopenia. A clinical manifestation of thrombocytopenia was symptomatic purpura in 3 patients (note that in the literature the frequency of symptomatic purpura is reported as around $35 \%)[1,3,10]$. In contrast to other observations in the literature we also noticed quite high elevation of D-dimers (100\% mean increase) and aminotrasferases (65\% mean increase). Dmoszyńska and Robak [2] suggests a mean D-dimer elevation of only in $15 \%$, which might explain the lack of the use of this marker in current guidelines for TTP $[1,3]$. According to current guidelines (UK 2012) only checks for APTT, INR and fibrinogen concentrations are recommended [3]. In our material elevation of D-dimers was present in all 14 hospitalizations. It could be suggested therefore that patients with thrombocytopenia, haemolytic anaemia and with some neurological disorders or elevated ALT/AST or D-dimers should trigger differential diagnosis towards TTP.

In all cases with suspicion of TTP there is also a need to exclude a secondary cause (Table 6), and to confirm the presence of inhibition and decreased concentration of ADAMTS-13 [1, 3, 9]. 
TABLE 6. Secondary reasons for thrombotic thrombocytopenic purpura $[1,3]$

Cause

\begin{tabular}{ll}
\multicolumn{1}{c}{ Cause } & \multicolumn{1}{c}{ Signs/symptoms } \\
\hline Congenital & $\begin{array}{l}\text { infant jaundice (rarely in children and adults), } \\
\text { ADAMTS13 below 5\% }\end{array}$ \\
\hline $\begin{array}{l}\text { Acute } \\
\text { idiopathic }\end{array}$ & IgG against ADAMTS-13 \\
\hline HIV & \\
\hline HCV/HBS & differential diagnosis with HELLP \\
\hline Pregnancy & Ticlopidin, Clopidogrel, statins, INF, Bleomycin \\
\hline Drug related & kidney transplant, bone marrow \\
\hline transplantation & transplantation \\
\hline $\begin{array}{l}\text { Neoplastic } \\
\text { disease }\end{array}$ & adenocarcinoma \\
\hline Pancreatitis & \\
\hline Rheumatology & systemic lupus erythematosus \\
\hline Surgery & vascular surgery \\
\hline
\end{tabular}

HIV - human immunodeficiency virus; HCV/HBS - hepatitis C/B virus infection; HELLP - haemolysis, elevated liver enzymes, and low platelets syndrome; INF interferon

In our study we confirmed the presence of inhibition and a decrease ADAMTS13 in 8 patients (in 2 patients with recurrent TTP these tests were not performed as clinical symptoms were used before the year 2000 for diagnosis). It should be remembered that tests for TTP (ADAMTS-13 concentration and inhibition) should be performed before plasma transfusion and plasmapheresis, because transfused plasma will supply metalloproteinase, and plasmapheresis will remove the inhibition.

Among the possible causes of TTP some drugs have been listed by other authors $[1,2,3]$. We also noticed such a relationship and a suspicion of drug-related TTP was considered in 4 cases. Two of these had taken a high dosage of non-steroidal painkillers (NSAID), 1 female had received Fluanox Depot, and 1 male had reported heroin drug abuse. In 2 patients with recurrent TTP, SLE was suspected (eventually confirmed only in 1 case). There was 1 patient with 3 recurrences of TTP. One patient developed TTP after vascular surgery. These findings are similar to those found by others in the literature $[1,3,9]$.

During treatment we used plasmapheresis and plasma transfusion, which is current practice [1, 2, 3, 4, 15]. Before starting plasmapheresis we transfused fresh frozen plasma (FFP) (about $30 \mathrm{~mL} / \mathrm{kg}$ body mass, followed by $40-60 \mathrm{~mL} / \mathrm{kg}$ together with plasmapheresis) $[1,2]$. The value and total plasma exchange ratio are not precisely defined in the literature [3]. Our observations suggested a better effect from using a double plasma exchange ratio rather than a lower ratio for TPE. This is in contrast to Canadian guidelines (where a 1.5× exchange ratio is recommended) $[3,16]$. When we first started using plasmapheresis (after the year 2000) we only used a $0.5^{\times}$exchange ratio - which ended up with more frequent TAD. Nowadays we prefer to use continuous plasmapheresis with a doubled exchange ratio ( $2 \times \mathrm{TPE})$.

Leading centres report promising results of performing TPE with the use of $50 \%$ plasma and $50 \%$ albumin concentration to reduce the risk of post-transfusion complications and viral infections [4].
An early start with glucocorticoids should also be considered from the first day of treatment if clinical symptoms suggest TTP [3]. In the group of patients receiving GKS later than the first day of treatment there were 2 deaths out of the hospitalizations. Moreover, the need for plasmapheresis lasted much longer in these hospitalizations. These findings are statistically significant and bounded with a linear relation (see the regression model given in the results). This means that the typical rise of PLT happens 4-5 days from starting GKS treatment. Any delay in starting GKS treatment causes a significant delay in the increase in PLT count. There was, however, no influence on survival rate (without TTP recurrence) in a follow-up. Nowadays, we start GKS immediately on the first day of treatment (following current guidelines) even though there is no evidence from a randomized trial confirming that this type of practice is effective [3].

In cases of resistance to classical treatment, defined as a lack of response up to the fifth treatment day, or progression of the disease up to the third day, we then start a second-line treatment based on immunosuppressive drugs [1, 2]. In our study we noticed the positive influence of cyclophosphamide in a cumulative survival rate analysis (F-Cox test $\mathrm{p}=0.032$ ). However, there was no difference in the Log-rank test ( $p>0.05)$, which suggests that immunosuppression based on cyclophosphamide seems to be initially more effective, but not exactly at the end of a long time observation. Early introduction of cyclophosphamide seems to be a promising alternative to other immunosuppressants in such cases. Nowadays, we always start cyclophosphamide in the case of the onset of new neurological symptoms. In contrast, in cases of new neurological or cardiological symptoms, Scully et al. prefer the use of rituximab (Mabthtera) (monoclonal anti-CD 20 antibody) or eculizumab [3]. There is a lack of randomized trials on this matter, and this remains an interesting option $[3,12]$. Unfortunately, this is a very expensive treatment, which in Poland might be reserved only to some of the most resistant cases. Additionally, rituximab has no registration for TTP treatment, and the occurrence of possible side effects or recurrence of TTP might trigger unexpected problems [17].

Diuretics play a role in supportive therapy, starting from the beginning of treatment, in order to reduce circulatory congestion and TAD. Two out of 10 patients developed circulatory disorders and resistant hypertension, which were reasons for transfer into ICU. Older patients seem to be usually at risk $[3,10]$. Our group, similar to other centres, contains patients of the mean age of $40 \mathrm{y}$ [4], but TAD was noticed even in younger patients. This seemed to be related to the volume of transfused plasma, as well as to micro-embolism in coronary vessels. Intensive Care Unit stay results in a longer hospital stay, which in cases of steroid use and central vein cannulation gave a higher risk of bacterial and/or viral infection.

Patients with TTP need detailed clinical examination, including blood culture and sensitivity tests in every case when blood temperature rises above $38^{\circ} \mathrm{C}$. In our study one patient developed sepsis during the ICU stay. Apart from diuretics we used blood transfusion during 12 hospitalizations because of 
symptomatic anaemia. Similar reports can be found in the literature $[1,3]$. In contrast to current guidelines, 5 of our patients received platelet transfusion, before diagnosis but after the onset of clinical symptoms - this did not seem to result in further deaths. Similar observations were made by George and Al-Nouri in a group of 64 patients $(33$ received platelet transfusions) [18]. However, there are reports pointing to a higher death rate after platelet transfusion - which is then recommended only in life-threatening bleeding complications, and in typical TTP it should be avoided [3]. Although our study did not confirm these findings, we agree that the transfusion of platelets in patients with suspected or confirmed TTP is contraindicated [3]. In our group, as in the study by George and Al.-Nouri, most of the platelet transfusions occurred in the other departments before admission to the Haematology Department.

An additional problem is the assessment of treatment effectiveness. It seems important to be aware that the rise in PLT should be constant. We have noticed a temporary decrease in PLT during treatment after an initial increase (but not normalization). Following other authors, we suggest that the constant continuation of treatment is necessary until: PLT count comes back to the normal limit (and remains stable for at least 2 days), LDH concentration decreases, and all neurological symptoms vanish $[1,3]$

Among biochemical haemolytic factors: initial bilirubin and reticulocyte count might be only slightly elevated. The LDH level seems to be quite a sensitive parameter. In our study LDH was elevated at least 2.5 times. However, neither initial LDH level nor the dynamics of its reduction has any relationship to the response to the treatment.

We achieved remission in 7 out of 10 patients, although only 5 patients remained in long term remission. These results are comparable to others centres $[1,3]$.

The literature dedicated to TTP does not supply any evidence of the influence of age on the remission rate [3]. In contrast, our study suggested that age $>55$ years might reduce the chance of survival without recurrence of TTP, as well as tachycardia (reflecting circulatory insufficiency). This was suggested in discriminate analysis.

In conclusion, it is important to highlight that TTP is a very rare condition, which results in a lack of properly supported guidelines based on strong scientific evidence (e.g. randomized trials, meta-analyses), for treatment and prognostic factors. Note that neither the authors of current guidelines (2012), nor the National Haematology Society (UK) take responsibility for the contents of the guidelines [3]. Although the major limitation of this study is the small number of patients, we submit these results with the hope that in the future these can be added to meta-analyses, and therefore to an improvement in appropriate recommendations.

\section{CONCLUSIONS}

1. Presence of tachycardia on TTP onset and age above 55 years is suggested to reduce survival and remission rates.

2. Remission of TTP seems to be helped by immunosuppression based on cyclophosphamide.

\section{REFERENCES}

1. Choroby wewnętrzne. Ed. A. Szczeklik. Medycyna Praktyczna, Kraków 2006, 1555-1568.

2. Dmoszyńska A., Robak T.: Podstawy Hematologii. Wyd. Czelej, Lublin 2008, 446-448.

3. Scully M., Hunt J.B., Benjamin S., Liesner R., Rose P., Peyvandi F. et al.: Guidelines on the diagnosis and management of thrombotic thrombocytopenic purpura and other thrombotic microangiopathies. Br J Haematol. 2012, 158 (3), 323-325.

4. O'Brien K.L., Price T.H., Howell C., Delaney M.: The use of 50\% albumin/ plasma replacement fluid in therapeutic plasma exchange for thrombotic thrombocytopenic purpura. J Clin Apher. 2013, 28 (6), 416-421.

5. George J.N.: Forecasting the future for patients with hereditary TTP. Blood. 2012, 120 (2), 243-244.

6. Machin S.J.: Clinical annotation. Thrombotic thrombocytopenic purpura. Br J Haematol. 1984, 56, (2), 191-197.

7. Pratt K.P.: Presenting ADAMTS13 on a TTP-associated MHC. Blood. 2013, 121 (17), 3302-3303.

8. Hoffman R., Benz E.J., Sanford J. Shattil, Furie B., Silberstein L.E. et al.: Thrombotic thrombocytopenic purpura and the hemolytic uremic syndrome. In: Hematology. Elsevier Inc., Churchill Livingstone 2009, 2099-2111

9. Levy G.G., Nichols W.C., Lian E.C., Foroud T., McClintickJ.N., McGee B.M. et al.: Mutations in a member of the ADAMTS gene family cause thrombotic thrombocytopenic purpura. Nature. 2001, 413, 488-494.

10. McPherson R.A., Pincus M.R.: Henry's clinical diagnosis and management by laboratory methods. Elseviere Saunders, Philadelphia 2011, 557-600.

11. Knovich M.A., Farland A., Owen J.: Long-term management of acquired thrombotic thrombocytopenic purpura using serial plasma ADAMTS13 measurements. Eur J Haematol. 2012, 88 (6), 518-525.

12. Bhagirath V.C., Kelton J.G., Moore J., Arnold D.M.: Rituximab maintenance for relapsed refractory thrombotic thrombocy topenic purpura. Transfusion. 2012, 52 (12), 2517-2523.

13. Kaushansky K.: The vWF-cleaving protease: new opportunities in TTP. Blood. 2001, 98 (6), 1643-1644.

14. George J.N.: Controlling chronic TTP. Blood. 2005, 106 (6), 1896.

15. Deford C.C., Reese J.A., Schwartz L.H., Perdue J.J., Kremer Hovinga J.A., Lämmle B. et al.: Multiple major morbidities and increased mortality during long-term follow-up after recovery from thrombotic thrombocytopenic purpura. Blood. 2013, 122 (12), 2023-2029.

16. Rock G.A., Sumak K.H., Buskard N.A., Blanchette V.S., Kelton J.G., Nair R.C. et al.: Comparison of plasma exchange with plasma infusion in the treatment of thrombocytic thrombocytopenic purpura. N Engl J Med. 1991, 325 (6), 393-397.

17. Goyal J., Adamski J., Lima J.L., Marques M.B.: Relapses of thrombotic thrombocytopenic purpura after treatment with rituximab. J Clin Apher. 2013, 28 (6), 390-394.

18. George J.N., Al.-Nouri Z.A.: Diagnostic ant therapeutic challenges in the thrombotic thrombocytopenic purpura and hemolytic uremic syndromes. Hematology Am Soc Hemat Educ Program. 2012, 1, 604-609. 